GEOGRAFICKÝ ČASOPIS / GEOGRAPHICAL JOURNAL 73 (2021) 4, 323-346

DOI: https://doi.org/10.31577/geogrcas.2021.73.4.17

\title{
CHILDREN'S INTERACTIONS WITH PUBLIC SPACE: OBSERVING CHILDREN'S EXPERIENCED AFFORDANCES IN A HOUSING ESTATE IN BRNO, CZECHIA
}

\author{
Daniel Kaplan* \\ * Masaryk University, Faculty of Science, Department of Geography, Kotlářská 2, 61137 Brno, Czechia, \\ 423712@muni.cz
}

\begin{abstract}
Children's interactions with public space: Observing children's experienced affordances in a housing estate in Brno, Czechia

The presented paper examines interactions between public spaces in a housing estate and children. Here, the relationship between the child and the environment is interpreted through the perspective of Gibson's affordances - an approach that has been employed many times since it appeared in different spatial contexts. Affordances are interactions/relationships between humans and the object or human and its environment. This research is focused on a housing estate in the Czech Republic in Brno. A non-participant covert observation was the main research method. Heft's functional taxonomy of children's affordances has been applied as a tool to classify these interactions and they are later confronted with the proposed variation in the taxonomy. The study includes modifications to the original taxonomy, adding a category (snow) and merging another (water). Other influences on children's affordances are adults (caretakers) and temporality as well as child body size, as the spectrum of active affordances differs between bigger and smaller children.
\end{abstract}

Key words: Heft's taxonomy, affordance, children's physical activity, public space, non-participant observation, housing estate Lesná in Brno

\section{INTRODUCTION}

Public space has been and remains a common topic in the fields of geography (Mitchel 1995, Goheen 1998, Pospěch 2013, Holubec, 2016, Terzi and Tonnelat 2017 and Cudny and Appelblad 2019), urban planning, design, architecture (Thompson 2002, Hamilton-Baillie 2008 and Gehl 2015) and sociology (Anderson 2015). Children's geographies have a similar interest in public space including outdoor activities, mobility, participation in decision-making, etc. (Percy-Smith 2010, Chaudhury et al. 2016, Bao et al. 2021 and Ender Altay et al. 2021). Its physical and social characteristics have led to many of the problems, i.e., criminality, aging po-pulation and the lack of commitment to the surrounding environment in housing estates (Yam et al. 2000, Ha 2008, Kristiánová, 2016 and Bogdanović-Protić et al. 2020). Despite the recent regeneration of housing estates many of these areas have been facing serious physical, social, environmental, and economic deterioration (Andráško et al. 2013, Šimáček et al. 2015 and Bogdanović-Protić et al. 2020). Public spaces in housing estates usually feature large green areas without more amenities (Mantey and Kępkowicz 2018), relatively large parking areas, and renovated playgrounds while also lacking in clarity and a lack of intimacy (Sendi et al. 2009 and Zalewski and Wojtak 2020). However, families who live in the housing estate spend time here and raise their children. While there has been research focusing on this public space (Kristiánová 2016), still rather little attention has been paid to children's activities in this context (Blazek 2015, Lehečka 2015, Andráško 2018 and Lehečka 2019). Overall, this article has the ambition to suggest another way we 
can interpret children's interactive relationship with the environment of the housing estate. In the context of the paper, the thoughts and results presented may provide support for local governments to draw children back into the public space of housing estates.

This paper uses affordances as a perspective to characterize the interaction of children with an environment. The original definition of affordances was provided by Gibson $(1979$, p. 127$)$ as "... what it offers the animal, what it provides or furnishes, either for good or ill.... I mean by it something that refers to both the environment and the animal in a way that no existing term does. It implies the complementarity of the animal and the environment." Affordances appear suitable for capturing interactions between a child's body and its environment. In recent years, there have been many studies examining affordances in various spaces (Aradi et al. 2016, Cushing and Pennings, 2017, Lerstrup and van den Bosch 2017 and Kyttä et al. 2018). Current research on public space and affordances is often concentrated on urban areas in Western Europe. Only a few exceptions, e.g. Kyttä (2002) have paid attention to public spaces in post-socialist countries or, as with Yatiman et al. (2012), in Malaysia, to rural spaces. We draw on the work of Heft (1988) and his functional taxonomy of children's affordances, as well as his followers Kyttä (2002), Norman (2013) and Lerstrup and van den Bosch (2017). The main objective of this article is to introduce and describe the physical affordances of children in the public space of a housing estate by utilizing the Heft's functional taxonomy and its other elaborations. As the taxonomy was created for public spaces in general, a few modifications were suggested which suit the public space of the housing estate. The research question is thus specified as follows: What physical affordances do children experience in the public space of a housing estate?

In the following section, I will introduce further research on affordances that this article is based upon, as well as the definition of affordances I work with. In the section on methodology, I will explain the methodology as children (participants) were divided by the size of their bodies for the purposes of research. The covert non-participant observation was chosen as the main research method. The informal interviews was a complementary method used to extend research and allow for deeper understanding of what was observed. A similar research method was used by Kyttä (2002), Bozkurt et al. (2018) or Chaudhury et al. (2019). In the sections "Discussion" and "Conclusion" a modification of the taxonomy in comparison with the original table and the alternatives of other authors is evaluated.

\section{AFFORDANCE}

The term comes from the verb 'to afford', and although the usage of this concept is widespread, especially in art science or perceptive psychology (Greeno 1994 and Chong and Proctor 2020). Our perspective of affordances is based on Gibson's work "The Ecological Approach to Visual Perception" (1979) and his subsequent followers, i.e., Norman (2013) and Heft (1988). He was the first to produce the idea that some objects can afford us a specific usage or interaction. Affordances break the dichotomy of subject-object, enabling us to understand its inadequacy, and they inform us about the animal and environment as well. As Gibson argues, people often see a subject through the meanings which they assign themselves, through someone else (Norman 2013) or through the process of learning (Goldstein 1981). This concept was then further elaborated by other authors 
(Heft 1988, Kyttä 2002, Niklasson and Sandberg 2010, Bozkurt et al. 2018 and Chaudhury et al. 2019) focusing more on children and their relationship with the environment.

The affordances of people in connection with public spaces also frequently occurs (Kesner 2009, Steenson and Rodger 2015). As some authors stated (Kyttä, 2002, Norman 2013 and Lerstrup and van den Bosch 2017), affordances should be helpful in creating or enriching a public space with objects which encourage interaction. Norman, a follower of Gibson's work, places affordances as a tool for designers. Not far from Gibson, he defines affordances as 'a relationship between the properties of an object and the capabilities of the agent that determine just how the object could possibly be used' (Norman 2013, p. 11). He even acknowledges that affordances can occur as person-to-person, yet he adds two more perspectives: signifiers and anti-affordances. A signifier is a perceivable sign or signal of what can be done. It is usually a feature that helps people discover the possibilities for interaction. This attempt to give our interactions (affordances) meaning is against Gibson's (1979) and Heft's (2003) argument that affordances should be direct and unmediated. The other term, anti-affordance, is a prevention of interaction. For example, the armrest on the bench helps to relax our arms, yet it might not afford one to lie down on the bench. Therefore, an object/person can afford activities and prevent them at the same time (Norman 2013).

According to Heft (1988), it is important to rise above the dichotomy of the physical and cultural environment. The subject perceives visually and mentally both in a given moment. Context and location also play an important role because location is a constituent aspect of its perceived meaning, while context is part of what is meaningfully perceived (Heft 2003). The fact that someone has taught us the cultural significance of an object or how to handle such an object does not mean that the object loses its other functions. Affordances are always unique and differ for each individual and each specific group of people. Therefore, the concept is well suited to describe the essential qualities of children's environments (Kyttä 2002).

Affordances are not only stable and rigid, but they are rather dynamic. They develop over time as a person evolves, and children are a great example of such dynamicity (Heft 2003 and Heft 2010). The environment has a close relationship with the perception of a child, which Heft addresses. He argues "that objects have affordances that are culturally normative use(s) of an object in particular contexts. For instance, many features in a home could function as a place to sit (i.e., they are properly scaled to the body for sitting) but normatively are not used in that way, and hence they are not normally perceived as serving that function" (Heft 2003, p 172).

There are many factors influencing outdoor children's activities (including affordance), yet there is one that stands out: caretakers. It is the caretakers' fear of danger in relation to the free movement of children in public spaces that Chaudhury et al. (2019) place great weight on. Caretakers are carriers of different behavioural patterns, creating negative and positive affordances for children through their bans and permits (Chen et al. 2020). They emphasise the danger (Valentine 1997) of meeting homeless people, traffic, unpredictable teenagers, and some children are aware of that sort of danger (Nordbakke 2019). Kyttä (2002) draws attention to the significant influence caretakers have on where their children can go outside. However, caretakers do not always have only a restrictive effect; 
through their outdoor presence, children might be encouraged to visit features or places they were afraid of before, or they are able to enjoy their stay outside more.

Since it began to be applied, affordances have been criticized by psychologists (Goldstein 1981, Greeno 1994 and Chong and Proctor 2020), architects (Overbeeke and Wensveen 2003 and Norman 2013), and in geography (Kyttä 2003) as well. Some authors even call affordances a "buzzword" (Overbeeke and Wensveen 2003 and Dotov et al. 2012). Others might argue that Gibson assert child uniform being yet and suggest that different variables (social status, urban/rural, gender, age and upbringing) have an influence on interactions with the environment (Matthews et al. 2000, Karsten 2003 and Shen et al. 2017). For example, Kyttä (2002) found a significant difference between Finnish and Belarusian children in terms of age and gender, especially when she utilized Heft's taxonomy in her research. Boys are more likely to use smooth slopes, whereas girls find more affordances in places such as the yard at home. While girls aged $7-9$, search the public space for objects such as trees, different climbing frames, and the like, boys of the same age prefer different shelters and houses. Age also plays an important role in terms of public and non-public spaces. Older children ( 7 to 9 ) tend to stay in more intimate and private spaces, such as shelters, shrubs, and tree houses, whereas younger children prefer open public places where they can play, exercise, or just hang out.

Few researchers have addressed the critique from new materialists that even objects like trees, benches, or even weather has its agency that needs to be examined. (Horton and Kraftl 2018). The world around us is created on a relational basis that allows nonhuman objects "to come alive", to have an agency. Rautio (2013) or Arvidsen (2018) even calls for disrupting long-lasting child-nature (re-connecting children to nature) relationship. Although affordances do acknowledge relationships between objects, this approach does not treat non-human objects as an equal, thus one might argue that we are losing significant part of information.

\section{Heft's functional taxonomy}

Based (mostly) on Gibson's conception of affordance, Heft constructed a functional taxonomy of children's affordances. His table is a valuable tool for understanding the environment from a child's perspective. This preliminary taxonomy is the output of the book One Boy's Day by Barker and Wright (1951) that is focused on observing children in their everyday activities. Heft noted every physical interaction with a feature, identified an affordance, and then classified them into ten groups. The name of the group was chosen based on the functional properties of a given feature. Each class was to be as distinctive as possible, yet, as Heft admits and others confirm (Lerstrup and van den Bosch 2017) or suggest (Storli and Hagen 2010 and Aradi et al. 2016), some changes might be necessary depending on the context. Despite its alterations, the taxonomy still remains relevant and useful as the mentioned papers demonstrate.

During Heft's research, children's physical interactions with the environment were studied and later classified, although issues of age, body scale, and weight were only briefly mentioned. However, possible differences in gender were not reflected at all, as suggested later by others (Kyttä 2002). Moreover, this taxonomy is predominantly focused on the physical affordances of children in public spaces, while there are other affordances, such as social (Chaudhury et al. 2019), emotional, and intellectual, illuminating further perceptions of public space by children (Cushing and Pennings 2017). In the context of perception and action, Kyttä (2002) 
distinguishes different levels of affordances: potential, perceived, utilised (independent interaction) and shaped (stimulated interaction) affordances.

Tab. 1. Heft's functional taxonomy of children's affordances

\begin{tabular}{ll}
\hline $\begin{array}{l}\text { Environmental qualities that support certain } \\
\text { affordances }\end{array}$ & Possible physical affordances \\
\hline Flat, relatively smooth surface & Walking, running, cycling, skating, skateboarding \\
Relatively smooth slope & $\begin{array}{l}\text { Coasting down (e.g. on bike, wagon), rolling down, } \\
\text { sliding, running down, rolling objects down } \\
\text { Drawing, scratching, throwing, hammering, batting, } \\
\text { spearing, skewering, digging, cutting, tearing, crump- } \\
\text { ing, squashing, building of structure }\end{array}$ \\
Graspable/detached object & $\begin{array}{l}\text { Sitting on, jumping on/over/down-from } \\
\text { Swinging on }\end{array}$ \\
Attached objects & $\begin{array}{l}\text { Exercise/mastery, looking out from, passage from } \\
\text { one place to another (stairs, ladder) }\end{array}$ \\
Non-rigid, attached object & $\begin{array}{l}\text { Locomotion from one place to another, looking and } \\
\text { listening into an adjacent place }\end{array}$ \\
Climbable feature & $\begin{array}{l}\text { Microclimate, prospect/refuge, privacy } \\
\text { Construction of objects, pouring, modification of its } \\
\text { surface features (e.g. sculpting) } \\
\text { Aperture }\end{array}$ \\
Shlashing, pouring, floating objects, swimming, div- \\
ing, boating, fishing, mixing with other materials
\end{tabular}

Source: Heft (1988).

\section{METHODOLOGY}

\section{Setting of observation}

Housing estates are scattered in urban areas all over the Czech Republic, even in small district towns. The research area of this study, the Lesná housing estate, lies in the north-eastern part of the city of Brno (Fig. 1.), three kilometres from the city centre. Due to its close connection with the surrounding nature, it is one of the most popular locations to live in and one of the top-rated housing estates in the Czech Republic (Andráško et al. 2013 and Kilnarová and Wittman 2017). An important element of Lesná is Čertova rokle (the Devil's gorge), which brings even more nature to the housing estate. In general, the surface is sloping with only several small, flat areas where parking lots or playgrounds are placed. Approximately 6,000 flats for approximately 20,000 people with an area of more than 1 square kilometres should be scattered throughout this landscape of forests and ravines (Zounek and Rudiš 1969). However, today there are only 16,000 inhabitants living in 8,100 flats as the original plans were not implemented (Český statistický úrad 2013). The reason for the decline is a demographic change of the housing estate since the majority of the inhabitants are older people, but they are constantly replaced by young families. This put pressure on the local government to adjust the environment in the housing estate. 


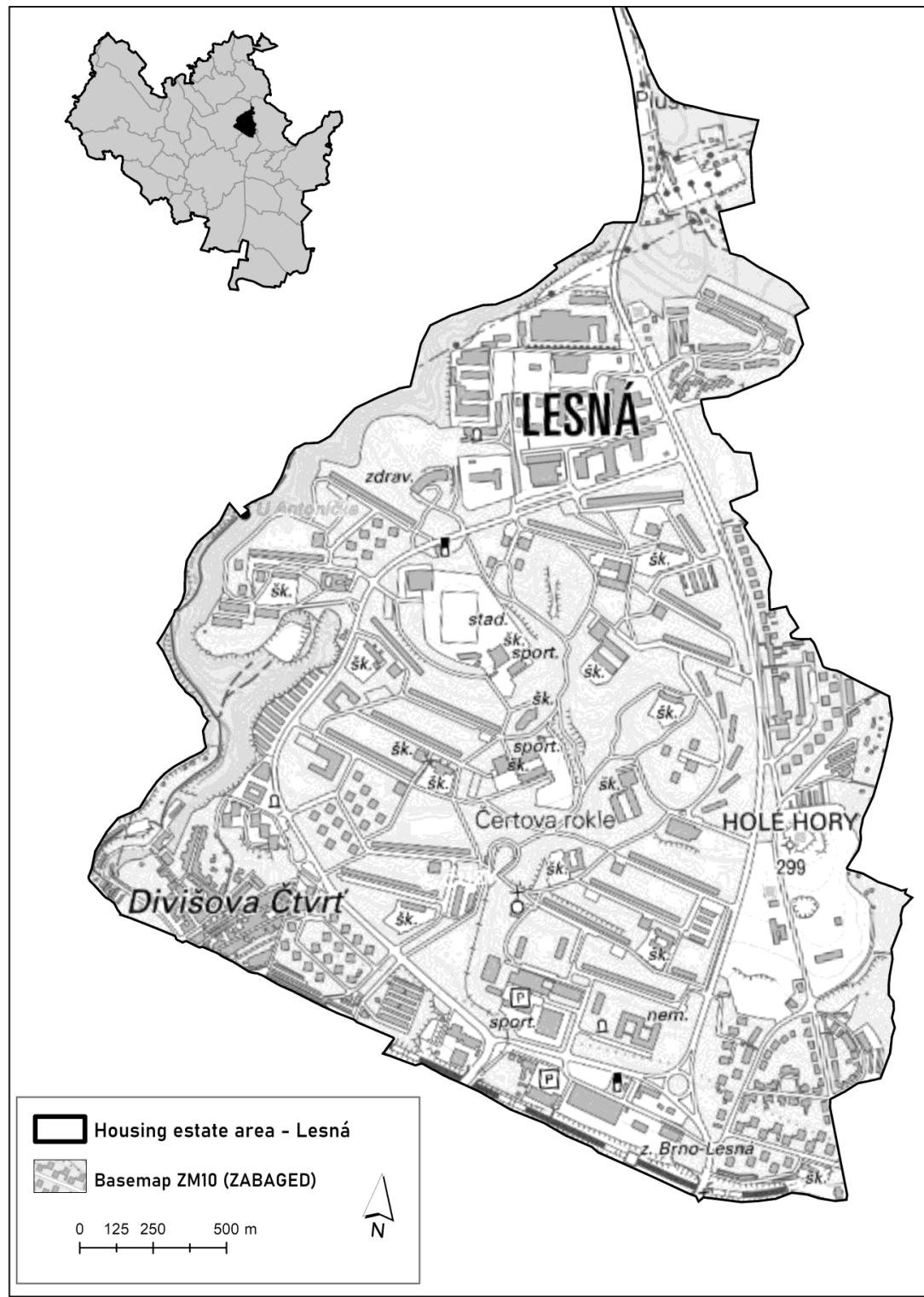

Fig. 1. Area of housing estate Lesná and its location within the city

The state of decay and pollution (dominantly coming from overfilled trash cans or containers) are a relatively common characteristic, but playgrounds are well maintained in general as well as the dense network of pavements. Another characteristic feature of the public space of this estate are the statues and decorative walls placed throughout the area. The art is physically accessible to everyone and made of solid and robust materials. There are several schools which utilise the large green areas and public playgrounds surrounding them for leisure activities. 


\section{Data collection}

The main research method was covert non-participant observation. Dis/advantages (ethics, voice of participant and researcher's bias) of this methodological approach are covered by a considerable body of literature (Švaříček and Šed'ová 2007, Liu and Maitlis 2010 and Stickdorn et al. 2018). This method was chosen due to the nature of the research as the author observed children's behaviour which should be undisturbed from knowing that they were participating in research (Walters and Godbold 2014 and Stickdorn et al. 2018). In specific research, results might be more valid then using participant observation or other methods (Hobson 2006). The author pretended to be just a passer-by and thus the risk of people being affected by the presence of a researcher was minimised. While the whole area is large, the observations gradually convened to specific places depending on the season of the year. During the warmer and sunnier periods, children concentrated on the streets and/or at the playgrounds, on the other hand, in the snowy winter these places were abandoned, and children spent their time on flat or sloppy green areas. Among others, short irregular informal interviews with caretakers or children about the true nature of the activities were also conducted, especially during the last stages of the research. These findings helped to better classify each interaction and came up with arguments for alternation. Interviews consist of $2-4$ questions regarding the children's activity.

Photography of the physical environment and the activities of children in the housing estate were taken during observing. All photographs were taken with the permission of the child and (if present) the caretakers, and the faces were later blurred. Simultaneously, the presenting of photographs depicting children have to be justified and considered to not harm vulnerable participants (Nutbrown 2010 and Phelan and Kinsella 2013). There was no collection of personal information and no formal interaction with the children.

The children were chosen as a social group to observe in these public spaces. Their actions are more spontaneous, colourful, and dynamic, and their daily activities are more diverse than adult behaviour in public spaces (Einarsdóttir 2007 and Wishart et al. 2019); therefore, their interactions with public spaces should be more diverse. Furthermore, they are led to spend more time outside compared to other age groups (Mäkelä et al. 2017) yet their time outside is lately constantly decreesing (Louv 2005) and the idea of a child-nature relationship is constantly challenged by Rautio (2013). The author of the study did not distinguish between children living in the housing estate and those living in nearby neighbourhoods as my main research question considers affordances which enable public space for children and families visiting this area as well. However, for the purpose of this research, the author distinguished between smaller and bigger children. Physical characteristics and territoriality (Lehečka 2015) especially are to some extent limited by the size of the body. This idea of body size and affordances was elaborated further in (Heft 2003, Jongeneel et al. 2015 and Sporrel et al. 2017) who proposed that simple physical interaction with the environment depends more on body than the age. There was no clear-cut line between bigger and smaller children. Apart from the size of the body the main clues for my observation were visible physical signs of the onset of puberty such as a deeper voice, facial hair, body mass, and a visible face condition. Toddlers and babies in strollers were excluded because they have limited independent interactions with the environment. 
During the observation, it was found that people in the housing estate are almost always on the move, be they walking on their way home or on their way to work or school. The author of the study had little observation of people resting or sitting, so he also tried to keep moving to fit. Field notes were first recorded on paper or as text on a tablet, and later it was opted to take audio recordings of notes and interviews. As the observation went on, the scope became narrower. The study focused exclusively on the interaction of the child with the environment and the context of their activities.

The observation in Lesná started on 18 October 2017 in autumn and ended it on 4 April 2019 in the spring. In the final months of the observation. The observer was looking for suitable stimuli to supplement the interpretive part and acquired additional visual material. In total, he spent 91 hours in the Lesná area during this period, during which 70 standard pages of field notes and 440 photographs were taken.

At first, the area was visited at lunchtime between 11:30 and 13:00. During these hours, the bustle of the housing estate was mainly produced by groups of children organized by schools or kindergartens moving around the Črtova rokle. However, the observation gradually became dependent on the end of the school day in local institutions when children are out of school and lately go outside as well. Every street of the housing estate was visited at least once, but gradually observations were organised in the places which seemed most appropriate during previous visits to the housing estate, those with some human activity.

\section{Data analysis}

Heft's table served as the basis for the interpretation of the activities observed in the housing estate, helping to describe them and add them to the specified categories. Each child's affordances from the field notes was named in a uniform way, such as running, walking, and cycling, to provide a comprehensive summary of the children's activities. The analysis of the visual material was like the text material. They were sorted according to the affordances captured.

The results were classified with the help of Heft's taxonomy; however, his classification did not recognize the characteristics of the estate's environment or the differences of the children physicality. Although it was necessary to make a few crucial adjustments to the taxonomy, most of the activities Heft lists in the table are observable in the estate's public spaces, although some may not be that common. Furthermore, various environment features may not be present in the housing estate. Another key change concerned the division between smaller and larger children, to which another table column was added to account for possible differentiation in affordances. There was also a classification problem with placing snow and ice in the correct category, as it is a state of water, but affordances of the snow were quite similar to those assigned to the materials. Therefore, snow as a separate category was added.

\section{RESULTS}

According to our observation, children proved to be the more physically active group compared to adults. Their affordances are usually connected with creative playing in public spaces. This could be a rather demanding task to be creative in the environment of the housing estate. Nevertheless, there were several findings from observations, which will be presented here with a focus on physically perceived affordances and their temporality. The division between smaller and bigger 
children is also considered. Each perceived affordances were classified according to Heft's taxonomy and some shortcomings in the context of the housing estate's public space were suggested.

Tab. 2. Heft's taxonomy adjusted to the observations of the housing estate

\begin{tabular}{|c|c|c|}
\hline $\begin{array}{l}\text { Environmental qualities } \\
\text { which support certain } \\
\text { affordances }\end{array}$ & $\begin{array}{l}\text { Possible physical } \\
\text { affordances of smaller } \\
\text { children }\end{array}$ & $\begin{array}{l}\text { Possible physical affordances } \\
\text { of bigger children }\end{array}$ \\
\hline $\begin{array}{l}\text { Flat, relatively smooth } \\
\text { surface }\end{array}$ & $\begin{array}{l}\text { Walking, running, cycling, } \\
\text { skating, skateboarding, } \\
\text { riding on a scooter }\end{array}$ & $\begin{array}{l}\text { Walking, running, cycling, skating, } \\
\text { skateboarding, longboarding, } \\
\text { sitting on }\end{array}$ \\
\hline Relatively smooth slope & $\begin{array}{l}\text { Coasting down, sliding, } \\
\text { running up and down }\end{array}$ & Coasting down \\
\hline Graspable/detached object & $\begin{array}{l}\text { Throwing, breaking, } \\
\text { drawing, kicking, building, } \\
\text { exercising, sitting-on }\end{array}$ & $\begin{array}{l}\text { Throwing, breaking, kicking, } \\
\text { exercising, sitting-on }\end{array}$ \\
\hline Attached object & $\begin{array}{l}\text { Sitting on, jumping over, } \\
\text { crawling, support for } \\
\text { writing, drawing, leaning }\end{array}$ & Sitting on, leaning \\
\hline Non-rigid attached object & $\begin{array}{l}\text { Swinging on, jumping } \\
\text { (trampoline) }\end{array}$ & Exercising \\
\hline Climbable object & $\begin{array}{l}\text { View, locomotion (stairs, } \\
\text { ladder, fence, tree) }\end{array}$ & Exercising, privacy, view \\
\hline Aperture & $\begin{array}{l}\text { Looking out, locomotion, } \\
\text { listening to }\end{array}$ & Privacy, intimacy \\
\hline Shelter & $\begin{array}{l}\text { Refuge, microclimate } \\
\text { (cold, shadow, lee) }\end{array}$ & $\begin{array}{l}\text { Privacy, intimacy, microclimate } \\
\text { (cold, shadow, lee) }\end{array}$ \\
\hline Mouldable material & $\begin{array}{l}\text { Building of objects, } \\
\text { adjusting of environment, } \\
\text { pouring over (gravel), } \\
\text { destruction, splashing, } \\
\text { mixing with other materials }\end{array}$ & Throwing \\
\hline Snow & $\begin{array}{l}\text { Throwing, sliding, building } \\
\text { of objects, adjusting } \\
\text { of environment }\end{array}$ & Throwing, sliding \\
\hline
\end{tabular}

\section{Relatively smooth slope}

The observed area is relatively sloping; therefore, regular transport includes these kinds of surfaces. There was little difference between smaller and larger children (dynamicity). The gorge inside the housing estate provides steep slopes that were occupied mainly in the winter snowy season. However, due to the safety of smaller children, they were often prohibited by their caretakers to go in there, on the other hand, larger children were often observed as they were running/riding down steeper slopes, and thus the spatiality of these affordances is different. Mounds (Fig. 2) were another interesting feature in the housing estate. These objects supplemented the lack of safer steep surface movements for smaller children; 
they ran up and down, threw each other down and competed to be standing on the highest mound.

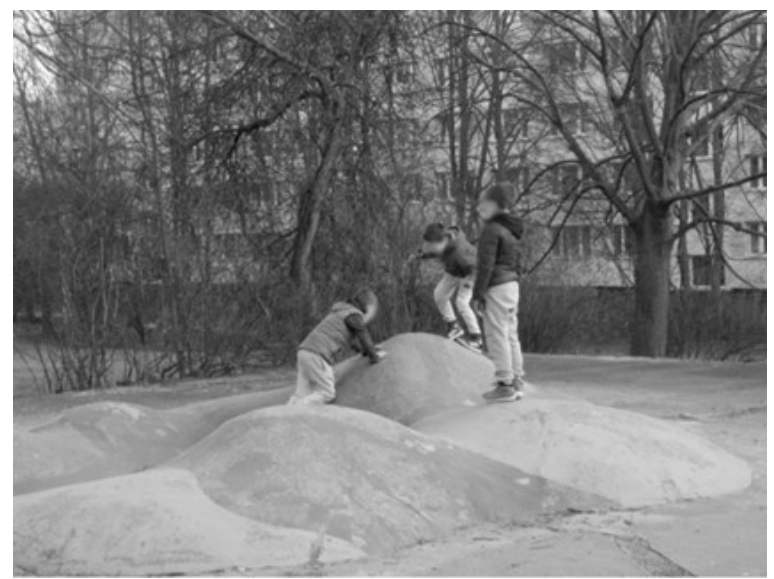

Fig. 2. Children exercising movement on sloppy terrain with moulds

\section{Graspable/detached object}

In the context of graspable objects, it is essential to establish what is a component of a public space and what is not. Furthermore, the physicality of children's bodies really matters, larger children can grasp more objects and interact with them more diversely. However, there are not many graspable objects in the housing estate except for benches and garbage cans. Children usually must bring something with them to the place, and these objects and their interactions with them were not included in the research. There are other exceptions, such as a playground full of toys that are free for everyone to use. These plastic shovels enable many affordances, such as digging, drawing in sand, or transporting materials. It was observed how groups of children have drawn pictures or game plans. It becomes a blank space which can be redesigned according to their own rules through the use of a rock.

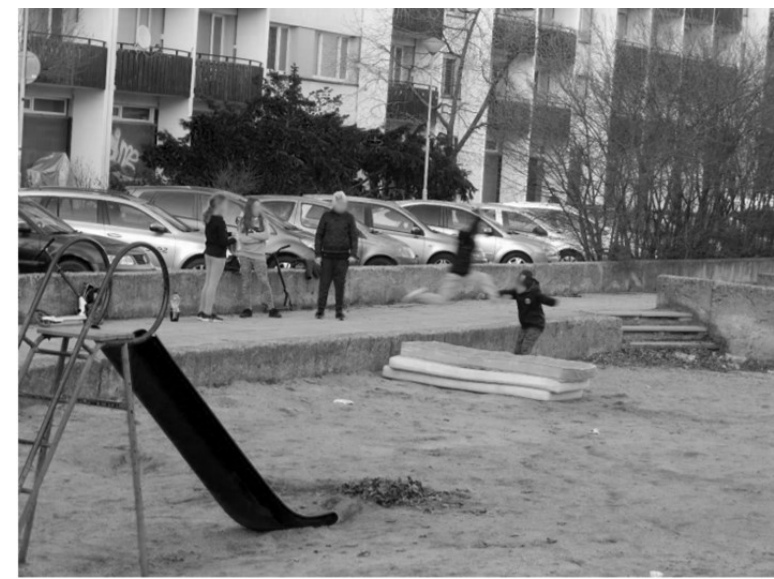

Fig. 3. Children playing with mattresses 
Sometimes, one triviality is enough to make monotonous spaces busy and offer new affordances which attract attention, such as mattresses (Fig. 3) that someone once left in the playground. Children suddenly used them to jump or exercise or build small houses or fortresses. In addition to mattresses, there was another interesting feature: an unsecured bench. It was a rather heavy but movable bench located in a large green space under trees. Almost every time when passing through this place, the bench was in a different position or place.

\section{Attached object}

The affordances of unmovable objects are again dependent on the physicality of the child. The blurred lines between other classes and affordances of attached objects were the most evident whenever smaller children interacted with such objects and they were provided with affordances that could be assigned to the other class. For example, smaller children cannot sit on high walls, and therefore, they can be classified as objects that enable vertical movement. However, they benefited from their small bodies when they were running around artistic features such as the one in the photography (Fig. 4). Moving to the non-artistic features of the housing estate, there are benches, small walls, fences, attached bins, table-tennis tables, wooden logs, and large stones. All of these objects are spread around the housing estate and are usually used to sit, jump over, or lie on.

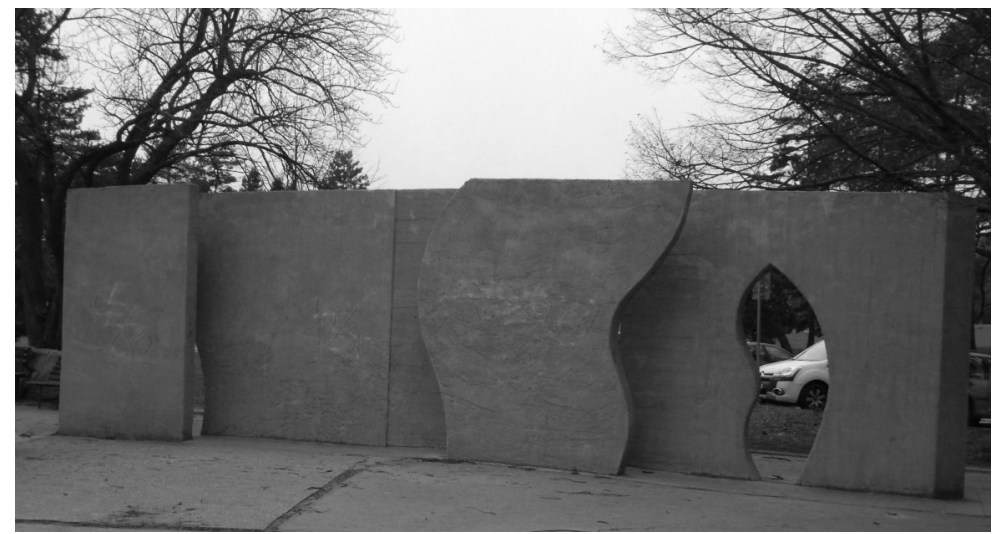

Fig. 4. Examples of an artistic feature smaller children were interacting with

\section{Climbable object}

The housing estate is relatively monotone in its offer of climbable objects. There are features such as ladders, slides, and other playground structures, as well as walls, stairs, and trees, many of which have cut lower branches that make vertical movement difficult for smaller children. Climbable objects provide privacy (Fig. 5), especially trees or objects with a small platform, where other children cannot enter, and the intentional or unintentional exercise of their bodies is restricted. These objects require a certain amount of physical strength and dexterity or the help of someone else, so that a child can get to the top of the attraction. Smaller children usually look for such objects in proportion to their size, and it often happens that they get to the top, but someone must help them back to the ground. 


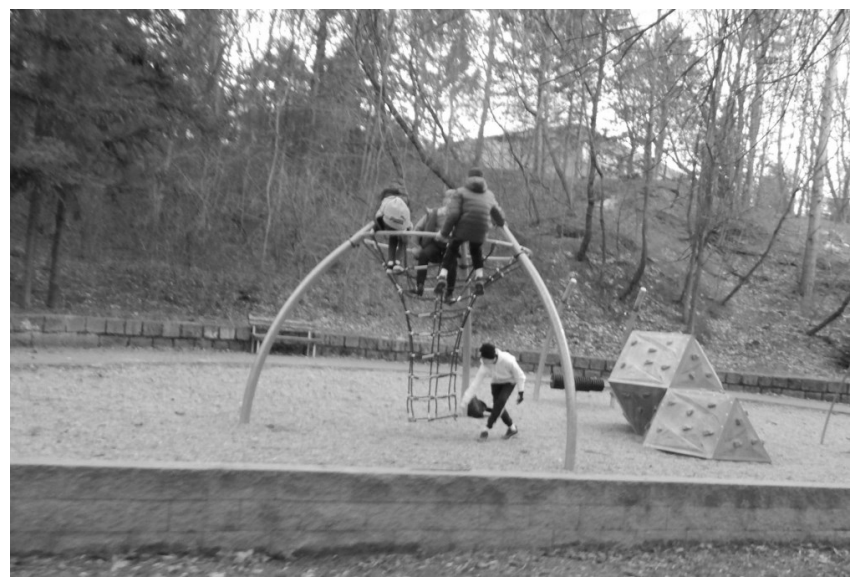

Fig. 5. Children using climbing frames as a sort of refuge

Flat, relatively smooth surface

The public space in housing estates is characterised by its openness. This allows almost any kind of movement, and there may be various well-trodden paths that indicate the most frequent movements of people through open green areas as a result. Smaller children move dynamically unpredictably and intermittently compared to adults or larger children. Sometimes they do not respect pavements or roads, they just run towards anything that catches their attention. They use these surfaces for transport on foot, by bike, by skateboard, or by scooter. Moreover, various surfaces (tarmac or pavement) may be used for drawing. They often do not even respect the paved path and, on the contrary, use the shortest possible. Bigger children usually do not run, and they tend to use less means of transport. Instead, they use flat places to sit down and chat.

\section{Non-rigid attached object}

These features and their affordances are often found in the playgrounds or close to them. An exception is tree branches, which can be used for swinging. They are used mostly by larger children. Swings enable swinging, but only if the children are big enough to swing by themselves; the same goes for the carousel; smaller children usually need the help of someone else. Another rather original feature of the playground was a trampoline. Bigger children used it to jump or exercise, doing tumbles or handsprings.

\section{Aperture}

Gaps and holes do not seem widespread in housing estates; there are no vistas or views of a larger scale due to the structure of the housing estate. However, there are some exceptions on a smaller scale. Statues or artistic features are probably the most interactive. There are dominant high walls with gaps or holes inside, and these narrow spaces are ideal for the (small) body of a child. When children were playing tag, they often used these objects as shortcuts to run away from larger children or caretakers. These objects are located close to playgrounds or parking lots. They allow children, for example, to hide, to sit, to climb, or to kick a ball against 
it. They can also stretch through climbing frames and other playground features. These gaps allow them to enter a place in a different way than a bigger body normally does, bigger children cannot easily stretch through most of these gaps, but they use them to assess the situation around them.

\section{Shelters}

The following two original categories are closely related to intimacy and privacy. The estate's gorge represents the largest shelter. It is rather steep, dark, and quiet. There are trees where you can hide from the sun. It is a shelter on its own. Certova rokle and its surroundings are used mostly by bigger children primarily looking for privacy and intimacy (smoking, drinking, or some romance). Winding roads and various twists are a frequent destination for them. On the other hand, smaller children and adults do not often use the gorge due to safety concerns.

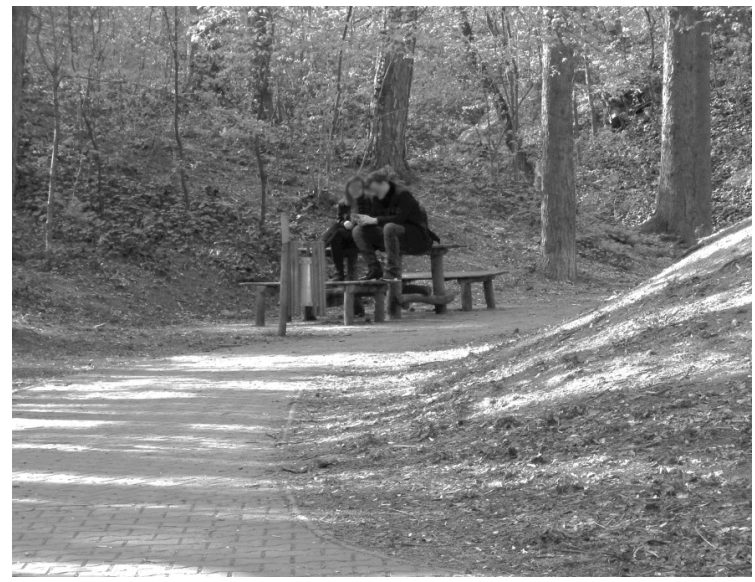

Fig. 6. Children experience refuge in the gorge

Affordances of shelter is one of the most diverse categories in the perception of larger and smaller children. Of course, it really depends on whether the child is under some form of supervision. However, larger children look for remote places with plenty of privacy for hanging out far away from supervision and omnipresent stares. A significant difference also lies in the meaning of using shelters. While smaller children use shelters primarily for playing soldiers or hiding-and-seek, seeking mostly games or play behind the search for shelter, larger children use them for privacy to do something they do not want to be seen doing Fig. 6 (smoking cigarettes, kissing and playing mobile games).

\section{Materials}

Children interact with various materials quite often. They can form it, build it, mark something, or throw it. However, affordances of materials depend on the seasons. While the sand is almost unused during winter, sandboxes are a frequent target of children's games in summer. This category is dominated by smaller children, besides throwing stones and cones, bigger children do not interact with materials. 
Sand is located in playground sandboxes and their surroundings; therefore, its affordances are limited to these places. Smaller children build castles, pyramids, or pies with the help of caretakers. They also draw abstract objects and create games like hopscotch in the sand. Another loose material is gravel. During spring, the gravel stays for a few weeks on the walkways, and it becomes a rather attractive material for children. They interact with gravel in the same way they do with sand, for example, building a grave for an insect (Fig. 7); the only difference is that these affordances occur close to walkways.

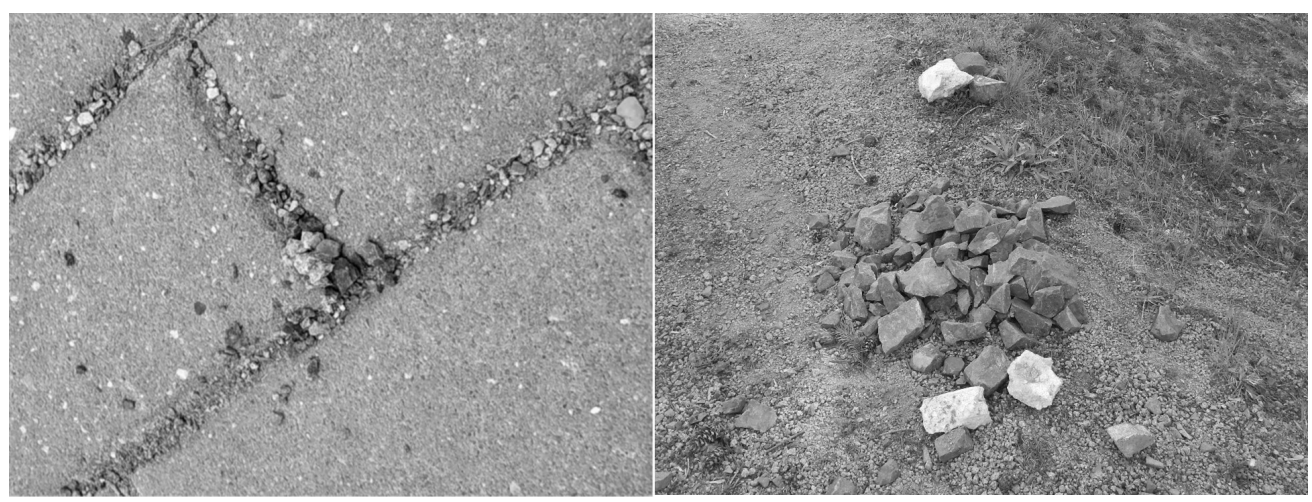

Fig. 7. Examples of children's affordances with materials

Finally, the last feature of public space is water. Unfortunately, there is no stable body or presence of water in the housing estate - there are, however, a few holes or other features which can retain some water. Therefore, the presence of water depends mostly on the weather conditions. These temporary water reservoirs are a good source of water to mix with other materials in the nearby playground and splash.

\section{Snow}

The observations in the winter showed that snow plays an important role in the lives of the people present in the housing estate. Snow, more than any other material, acts as an affordance and anti-affordance. Wet snow appears as a barrier to the green empty areas where many pavements are present, and larger children especially avoid them. Their movement is slow, careful and they use gravel-gritted walkways. However, smaller children really enjoy snow; they build fortresses, walls, or snowmen, and they throw snowballs or make snow angels.

\section{Caretakers}

Here, the author draws from Norman's conception of affordances as a person-to -person relationship, since adults, and especially caretakers, dis/enable various affordances. When moving in a public space, caretakers create barriers and help overcome them. The most significant affordances caretakers given to children is to provide safe movement. Caretakers are the most important factor influencing a child's spatial behaviour. However, their presence in space not only affects the spatial movement of children but also its dynamism: When children are close to their 
caretakers, they allow themselves to go places where they would not go without the presence of their caretakers.

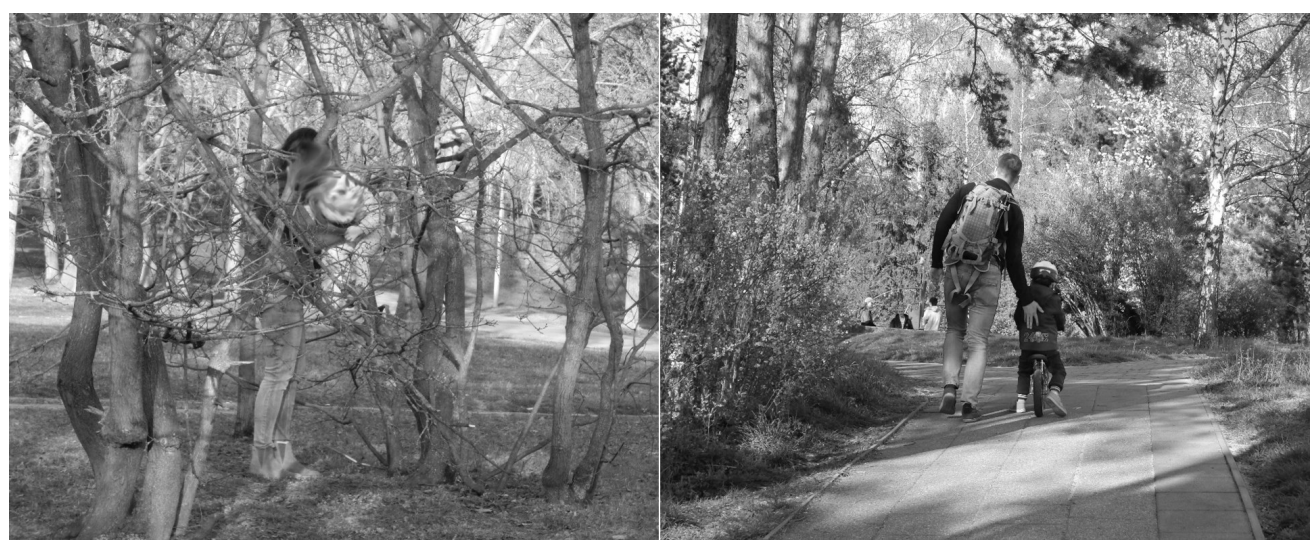

Fig. 8. Caretakers helping children and extending their possible affordances

An important component is also the care of caretakers for their child's safety and basic needs, such as helping small children to get off trees or attractions. Based on this, it can be argued that caretakers serve as an affordance, allowing children a certain kind of movement (Fig. 8). On the other hand, fear can also be approached negatively through various bans or simply by holding a hand while walking. Caretakers sometimes use a public space for children as a place to learn. Smaller children learn to ride a bike, kick a ball, throw a frisbee, or, with bigger children, play table tennis. In most cases, caretakers try to be actively involved in teaching and demonstrate how to do things right, what features or branches to grasp, what to do with a shovel, or how to use certain objects. The children then imitate their movements.

\section{Temporariness}

Lerstrup and van der Bosch (2017) found several characteristics of significance in the characteristics children choose, such as abundance, novelty, change, uniqueness, variation, gradation, and size. It can be only agreed and confirmed that these characteristics are important, although another view on change and novelty could be offered. There are places or features that attract more attention when they suddenly appear in space. These might be features whose characteristics might change temporally. And, it does not need to be a new object, as in the case of old mattresses was mentioned earlier: the garbage that children brought to the playground and was later gone. Kids find other features, such as wooden signs, snow, gravel, fallen leaves, cut down trees and so on. Lerstrup and van der Bosch's characteristics matter, but temporality and change stand above them in the context of the housing estate.

\section{DISCUSSION}

Although the presented findings did mostly prove that Heft's taxonomy could be utilized for the environment of a housing estate. A few alternations and recommendations for future research could be suggested. Observations were conducted 
over two winter seasons, and therefore a new class, snow, an element that has not been emphasised enough in previous works (Wilkinson et al. 1980, Fjørtoft and Sageie 2000, Ergler et al. 2016, Rautio and Jokinen 2016, Lerstrup and van der Bosch 2017 and Andráško 2018) could be defined. The presence of snow completely changed the spectrum of affordances as well as their spatiality. Suddenly children's interactions with the environment were rarely observed and playgrounds - the seasonal centres of the children's activities and childhood itself were mostly abandoned (Gudova 2016). This paper reflects the possibilities of research outside of "central" western urban landscapes by western concepts, as their utilization might differ from other parts of the world in terms of socio-spatial context and physical public spaces of housing estates (Andráško 2018).

The body's physicality plays a crucial role when experiencing affordances of the environment. The most noticeable differences of such an experience are in class attached objects and climbable objects. It is not exclusively the size of the body that matters, but sometimes strength makes differences too. Other divisions between bigger and smaller children are in experiencing affordances of the shelters. Hidden places provide bigger children more privacy and intimacy (Arvidsen and Beames 2019) and they usually intentionally (Stevens 2007 and Woodyer 2012) look for such places, however, smaller children seek for them predominantly as part of the game thus unintentionally during their free time. It can be argued that Heft (1988) does not account for the age, size, physical condition, or even gender of children which he later recognized in his work (Heft 2003 and 2010). Nonetheless, based on findings, it could be argued that when using Heft's functional taxonomy, we should be aware of differences in the children's bodies. Therefore it would be more appropriate to focus on a narrower group of children or specify classes of children according to their physical appearance.

Compared to the work of Lerstrup and van der Bosch (2017), suggested taxonomy does not reflect the size of the features in the public space but size of the children's bodies. A slightly different label for other characteristics which influence children's affordances was created as a caretaker could easily be replaced by another person or a novelty and variation through temporariness. Another characteristics (abundance or unknown/not easily accessible space) they mentioned were also present, yet not of the same intensity.

According to findings, smaller children usually spend their time outside with caretakers who protect them (Nordbakke 2019 and Chen et al. 2020), and therefore their presence is crucial to providing affordances. Nonetheless, the caretaker might provide a wider spectrum of affordances as well as narrow it down. Parents usually give their children verbal or physical bans on doing something, therefore they provide anti-affordances (Norman 2013). Considering other Norman's terms, caretakers also act as a signifier, they provide a visual or verbal hint for children to interact with the environment in a specific "right" way.

As it stands, Heft's taxonomy is a useful tool to describe children's interactions with the environment and classify affordances in public spaces. However, there are a few issues which have appeared during the research. Some classes, like materials or unmovable objects, might have blurred borders between each other. Depending on the distribution, classifications in the table might offer different affordances. Materials might offer affordances like sitting or jumping over. For example, wooden logs are materials, but they are also unmovable objects. Viewing possible affordances from a child's perspective and within the context really does matter. A 
$\log$ is an unmovable object, as is a bench or fence; children will probably not use logs as material for their activities.

It was also recognised that, while encompass the entire spectrum of children's activities in Lesná, this does not imply that affordances which were not observed are not present in the public space, as it was stated before. Although, the study focused on the physical affordances of the environment, there are plenty of other affordances that need more examination, such as social (Kyttä 2003), emotional, or intellectual ones (Cushing and Pennings 2017). Only a small insight into how another person (caretaker) could provide possible respectively activity affordances to the child was provided. However, it can be argued that affordances such as privacy or intimacy are also an emotional or social affordance, but the taxonomy considers only physical affordances.

Another limitation of the taxonomy in the context of the housing estate is the lack of water features. The class of water is narrow, with only a few affordances usually referring to playing in temporary puddles. Therefore, it was included it among materials. In light of the new materialism, mundane and perennial materials like branches, rocks (Horton and Kraftl 2018) or gravel as its own presence or quality make us interact with them (Rautio 2013). Without them there could not be any dens (Arvidsen 2018), tombs, or fortresses. Without its seasonal presence, most of these affordances would not be provided. Of course, it is not the case exclusively for materials but for all features in the public space, yet materials stand out as their temporariness or presence is more variable.

The art in public space is another specific category which might deserve its own category in Heft's taxonomy. Artistic features are becoming omnipresent as well as becoming more accessible to physical interaction. Children's contact with statues is documented in the work of Cushing and Pennings (2017) as they provide a considerable range of physical and non-physical affordances and attract their activities. To put this in the wider context of creating the public space, van Andel (1990) has suggested that place preference is related to the function and its affordances. A preferred place is likely to be used, and conversely, it is unlikely to be used if it is less preferred. Hence, the factors that influence environmental preferences are the factors that also influence the actualization of environmental affordances. The point that should be made here is to emphasise the importance of art, not only for aesthetic (Cudny and Appelblad 2019) reasons, but for its interaction as well, although the utilization of such areas might be controversial (Kesner 2009 and Bureš 2021).

\section{CONCLUSION}

The results of this study indicate that children experience a wide spectrum of physical affordances in the public space of the Lesná housing estate, as shown in presented altered classification. The presence of affordances in the public space here are dependent on the spatial context (time of the year, terrain, traffic, accessibility, equipment, etc.) of a given place for example well equipped playgrounds could be seen as the buzzing nest of affordances. This leads to the saturation of works dealing with affordances in the playground such as Wilkinson et al. (1980), Jongeneel et al. (2015), Gudova (2016) and Graham et al. (2021). Despite this other specific places do not get much attention. Most of the features of the public spaces are unmovable; thus, there is a lack of affordances, such as for throwing or carrying. However, there are exceptions that appear attractive and valuable for chil- 
dren (materials, light objects - benches and signs). Statues or walls seem to be essential features, providing a decent scale of affordances in public spaces. Overall, the moveable objects usually attract more attention of a child and encourage them to be creative and playful. The studied public space is lacking in such features, and thus may be a reason why few are so attractive. The temporality of possible affordances are also appealing to children. There are materials such as snow, gravel, and water puddles that appear only at certain times of the year. Its attractivity for children affordance might come from the abundance of such a material (Lerstrup and van der Bosch 2017).

This research has highlighted the few limitations of Heft's taxonomy and suggests an alternation - adding class "snow" and two variables that have influenced experienced affordances - for future utilization. Another crucial addition to Heft taxonomy was suggested in order to divide or at least consider the division of children by their physicality. This does not imply that other variables such as class, race, urbanity/rurality (Kyttä 2004) are not significant enough, yet the size of the body seems to be somehow overlooked with only a few exceptions which have recently appeared (Heft 2003, Jongeneel et al. 2015 and Sporrel et al. 2017). Bigger children, unlike the smaller ones, experience their affordances differently. Their affordances are more similar to an adult's experience. Unlike smaller children who play outdoors a lot, they spend less time outdoors, and, if so, they do so in more hidden, intimate places. Furthermore, their activities seem to be more intentional. Smaller children do not wander too far from home and are satisfied with a smaller overall space for movement. Furthermore, they spend more time in playgrounds or other designated places due to greater supervision where they enjoy opportunities that the environment can afford. Playing or games appear as the main motivation for the physical interaction of small children with the environment.

This work was supported by the Technology Agency of the Czech Republic (Strategic tools for building a barrier-free city, TL01000013). The author is very thankful for this support.

\section{REFERENCES}

ANDERSON, E. (2015). "The White Space." Sociology of Race and Ethnicity. 1, 10-21. DOI: https://doi.org/10.1177/2332649214561306

ANDRÁŠKO, I. (2018). "East meets West" - on studying "Eastern" housing estates through "Western" concepts and approaches. Urban Development Issues, 55(3), 3-18. DOI: https://doi.org/10.2478/udi-2018-0001

ANDRÁŠKO, I., LESOVÁ, P., KUNC, J., TONEV, P. (2013). Perception of quality of life in Brno housing estates. Hungarian Geographical Bulletin, 62, 90-101.

ARADI, R., THORÉN, K. H., FJØRTOFT, I. (2016). The urban landscape as affordance for adolescents' everyday physical activity. Landscape Research, 41, 569-584, DOI: https://doi.org/ https://doi.org/10.1080/01426397.2015.1077943

ARVIDSEN, J. (2018). Growing dens. On re-grounding the child-nature relationship through a new materialist approach to children. Children's Geographies, 16, 279-291. DOI: https://doi.org/10.1080/14733285.2018.1425371

ARVIDSEN, J., BEAMES, S. (2019). Young people's outdoor refuges: Movements and (dis)entanglements. Children's Geographies, 17, 401-412. DOI: https://doi.org/ 10.1080/14733285.2018.1529860

BAO, Y., GAO, M., LUO, D., ZHOU, X. (2021). Effects of children's outdoor physical activity in the urban neighbourhood activity space environment. Frontiers in Public Health, 9, 1-11. DOI: https://doi.org/10.3389/fpubh.2021.631492 
BARKER, R. G., WRIGHT, H. F. (1951). One boy's day; a specimen record of behaviour. New York (Harper).

BLAZEK, M. (2015). Rematerialising children's agency. Bristol (Policy Press). DOI: https://doi.org/10.1332/policypress/9781447322740.001.0001

BOGDANOVIĆ PROTIĆ, I., MITKOVIĆ, P., VASILEVSKA, L. (2020). Toward regeneration of public open spaces within large housing estates - A case study of Niš, Serbia. Sustainability, 12, 24. DOI: https://doi.org/10.3390/su122410256

BOZKURT, M., WOOLLEY, H., DEMPSEY, N. (2018). Children's interactions with water in city centres: A case study from Sheffield, UK. Landscape Research, 44, 671-687. DOI: https://doi.org/10.1080/01426397.2018.1518518

BUREŠ, V. (2021). Je to průšvih hlavně rodičů, říká historik k sáňkování na ruinách v Lidicích. In iDnes.cz [online]. Praha (Mafra), [Online]. Available: https://www.idnes.cz/ zpravy/domaci/sankovani-buchenwald-lidice-pieta-stehlik.A210119 095727 zahranicni bur [accessed 25 October 2021].

ČESTKÝ STATISTICKÝ ÚŘÁD. (2013). Statistický lexikon obcí - 2013, [Online]. Available: https://www.czso.cz/documents/10180/24336427/4116130557.pdf/452ff094-a50144ab-8a63-9effe7693e97?version=1.0 [accessed 25 October 2021].

CHAUDHURY, M., OLIVER, M., BADLAND, H. M., MAVOA, S. (2016). Public open spaces, children's independent mobility. In Evans, B., Horton J., Skelton, T., eds. Play and recreation, health and wellbeing. Geographies of Children and Young People, 9, Singapore (Springer), pp. 1-22. DOI: https://doi.org/ 10.1007/978-981-4585-51-4 17

CHAUDHURY, M., HINCKSON, E., BADLAND, H., OLIVER, M. (2019). Children's independence and affordances experienced in the context of public open spaces: A study of diverse inner-city and suburban neighbourhoods in Auckland, New Zealand. Children's Geographies, 17(1), 49-63. DOI: https://doi.org/ 10.1080/14733285.2017. 1390546

CHEN, Ch., YUAN, Z., ZHU, H. (2020). Playing, parenting and family leisure in parks: Exploring emotional geographies of families in Guangzhou Children's Park, China. Children's Geographies.18, 463-476. DOI: https://doi.org/ 10.1080/14733285. 2019.1676879

CHONG, I., PROCTOR, R. W. (2020). On the evolution of radical concept: Affordances according to Gibson and their subsequent use and development. Perspectives on Psychological Science, 15, 117-132.

CUDNY, W., APPELBLAD, H. (2019). Monuments and their functions in urban public space. Norsk Geografisk Tidsskrift - Norwegian Journal of Geography, 73, 273-289. DOI: https://doi.org/10.1080/00291951.2019.1694976.

CUSHING, D. F., PENNINGS, M. (2017). Potential affordances of public art in public parks: Central Park and the High Line. Proceedings of the Institution of Civil Engineers. Urban Design and Planning, 170, 245-257. DOI: https://doi.org/10.1680/jurdp. 16.00042

DOTOV, D., NIE, L., De WIT, M. (2012). Understanding affordances: History and contemporary development of Gibson's central concept. Avant, 3, 28-39.

EINARSDÓTTIR, J. (2007). Research with children: methodological and ethical challenges. European Early Childhood Education Research Journal, 15, 197-211. DOI: https:// doi.org/10.1080/13502930701321477

ENDER ALTAY, E., ŞENAY, D., EYÜPOĞLU, Z. (2021). Outdoor indicators for the healthy development of children. Child Indicators Research, 14, 2517-2545. DOI: https://doi.org/10.1007/s12187-021-09855-8

ERGLER, CH. K., KEARNS, R., WITTEN, K. (2016). Exploring children's seasonal play to promote active lifestyles in Auckland, New Zealand. Health \& Place, 41, 67-77. DOI: https://doi.org/ 10.1016/j.healthplace.2016.07.001

FJØRTOFT, I., SAGEIE, J. (2000). The natural environment as a playground for children: Landscape description and analyses of a natural playscape. Landscape and Urban Planning, 48, 83-97. 
GEHL, J. (2015). "Three types of outdoor activities," "Life between buildings," and "Outdoor activities and the quality of outdoor space. In Legates, R. T., Stout, F., eds. The city reader. New York (Routledge, Taylor \& Francis Group), pp. 608-617.

GIBSON, J. J., (1979). The ecological approach to visual perception. New York. (Psychology Press).

GOHEEN, P. G. (1998). Public space and the geography of the modern city. Progress in Human Geography, 22, 479-496. DOI: https://doi.org/10.1191/030913298672729084

GOLDSTEIN, E. B. (1981). The ecology of J. J. Gibson's perception. Leonardo, 14, 191 195.

GRAHAM, M., WRIGHT, M., AZEVEDO, L. B., MACPHERSON, T., JONES, D., INNERD, A. (2021). The school playground environment as a driver of primary school children's physical activity behaviour: A direct observation case study. Journal of Sports Sciences, 39, 2266-2278. DOI: https://doi.org/ 10.1080/02640414.2021.1928423

GREENO, J, G. (1994). Gibson's affordances. Psychological Review, 101, 336-342. DOI: https://doi.org/10.1037/0033-295X.101.2.336

GUDOVA, E. (2016). 'Slow! Children at play': Localization of childhood in Moscow playgrounds in winter. Working Paper, National Research University Higher School of Economics, Moscow. DOI: https://doi.org/ 10.2139/ssrn.2881279

HA, S. (2008). Social housing estates and sustainable community development in South Korea. Habitat International, 32, 349-363 DOI: https://doi.org/ 10.1016/j.habitatint. 2007.11.005

HAMILTON-BAILLIE, B. (2008). Towards shared space. Urban Design International, 13, 130-138. DOI: https://doi.org/10.1057/udi.2008.13

HEFT, H. (1988). Affordances of children's environments: A functional approach to environmental description. Children's environments quarterly, 5(3), 29-37.

HEFT, H. (2003). Affordances, dynamic experience, and the challenge of reification. Ecological Psychology, 15, 149-180. DOI: https://doi.org/10.1207/S15326969ECO1502_4

HEFT, H. (2010). Affordances and perception of landscape: An inquiry into environmental perception and aesthetics. In Ward Thompson, C., Aspinall P., Bell, S., eds. Innovative approaches to researching landscape and health. London (Routledge), pp. 9-32.

HOBSON, A. J. (2006). Guilt, betrayal and utilitarian ethics: Research participants' experiences of covert participant observation. In Kozuh, B., Kahn, R., Kozlowska, A., Krope, P., eds. Description and explanation in educational and social research. Warsaw (Rodn "WOM" Publishers), 51-65.

HOLUBEC, P. (2016). Od veřejného prostoru k autonomii urbánní formy. In Vondráčková, S., ed. Veřejný prostor a veřejná prostranství. Almanach Katedry urbanismu a územního plánování 2016. Praha (České vysoké učení technické), pp. 25-38.

HORTON, J., KRAFTL, P. (2018). Rats, assorted shit and 'racist groundwater': Towards extra-sectional understandings of childhoods and social-material processes. Environment and Planning D: Society and Space, 36, 926-948. DOI: https://doi.org/ $10.1177 / 0263775817747278$

JONGENEEL, D., WITHAGEN, R., ZAAL, F. T. J. M. (2015). Do children create standardized playgrounds? A study on the gap-crossing affordances of jumping stones. Journal of Environmental Psychology, 44, 45-52. DOI: https://doi.org/ 10.1016/j.jenvp. 2015.09.003

KARSTEN, L. (2003). Children's use of public space: The gendered world of the playground. Childhood: A Journal of Global Child Research, 10, 457-473. DOI: https:// doi.org/10.1177/0907568203104005

KESNER, L. (2009). Intence, afordance a význam kulturních objektů. In Kroupa, J., Šeferisová Loudová M., Konečný L., eds. Orbis Artium. Brno (Masarykova univerzita), pp. 59-73.

KILNAROVÁ, P., WITTMANN, M. (2017). Open space between residential buildings as a factor of sustainable development - Case studies in Brno (Czech Republic) and Vienna (Austria). IOP Conference Series: Earth and Environmental Science, 95(5), 1-12. DOI: https://doi.org/10.1088/1755-1315/95/5/052008 
KRISTIÁNOVÁ, K. (2016). Post-socialist transformations of green open spaces in large scale socialist housing estates in Slovakia. Procedia Engineering, 161, 1863-1867. DOI: https://doi.org/10.1016/j.proeng.2016.08.715

KYTTÄ, M. (2002). Affordances of children's environments in the context of cities, small towns, suburbs and rural villages in Finland and Belarus. Journal of Environmental Psychology, 22, 109-123. DOI: https://doi.org/10.1006/jevp.2001.0249

KYTTÄ, M. (2003). Children in outdoor contexts. Affordances and Independent Mobility in the Assessment of Environmental Child Friendliness. Dissertation thesis. University of Technology, Helsinki.

KYTTÄ, M. (2004). The extent of children's independent mobility and the number of actualized affordances as criteria for child-friendly environments. Journal of Environmental Psychology, 24, 179-198. DOI: https://doi.org/10.1016/S0272-4944(03)00073-2

KYTTÄ, M., OLIVER, M., IKEDA, E., AHMADI, E., OMIYA, I., LAATIKAINEN, T. (2018). Children as urbanites: mapping the affordances and behaviour settings of urban environments for Finnish and Japanese children. Children's Geographies, 16, 319-332, DOI: https://doi.org/10.1080/14733285.2018.1453923

LEHEČKA, M. (2015). "Když nám tam chtěl hrát někdo cizí, tak sme ho třeba vykamenovali": Reflexe vtělené zkušenosti vyrůstání na sídlišti. Biograf, 61, 35-62.

LEHEČKA, M. (2019). „Pocity plotu“: teritoriální (re)produkce, normativita a ne/ viditelnost ve veřejném prostoru panelového sídliště. Sociální studia, 16, 57-77. DOI: https://doi.org/10.5817/SOC2019-1-57

LERSTRUP, I., van den BOSCH, C. K. (2017). Affordances of outdoor settings for children in preschool: Revisiting Heft's functional taxonomy. Landscape Research, 42, $47-$ 62. DOI: https://doi.org/10.1080/01426397.2016.1252039

LIU, F., MAITLIS, S. (2010). Nonparticipant observation. In Mills, A., Durepos, G., Wiebe, E., eds. Encyclopedia of case study research. Thousand Oaks (SAGE Publications), pp. 610-612. DOI: https://doi.org/10.4135/9781412957397

LOUV, R. (2005). Last child in the woods: Saving our children from nature deficit disorder. New York (Algonquin Books of Chapel Hill).

MÄKELÄ, S., AALTONEN, S., KORHONEN, T., ROSE, R. J., KAPRIO, J. (2017). Diversity of leisure-time sport activities in adolescence as a predictor of leisure-time physical activity in adulthood. Scandinavian Journal of Medicine and Science in Sports, 27, 1902-1912.

MANTEY, D., KĘFOWICZ. A, (2018). Types of public spaces. The Polish contribution to the discussion of suburban public space. The Professional Geographer, 70, 633-654. DOI: https://doi.org/10.1080/00330124.2018.1443475

MATTHEWS, H., TAYLOR, M., SHERWOOD, K., TUCKER, F., LIMB, M. (2000). Growing-up in the countryside: children and the rural idyll. Journal of Rural Studies, 16, 141-153. DOI: https://doi.org/10.1016/S0743-0167(99)00059-5

MITCHELL, D. (1995). The end of public space? People's park, definitions of the public, and democracy. Annals of the Association of American Geographers, 85, 108-133. DOI: https://doi.org/10.1111/j.1467-8306.1995.tb01797.xa

NIKLASSON, L., SANDBERG, A. (2010). Children and the outdoor environment. European Early Childhood. Education Research Journal, 18, 485-496. DOI: https://doi.org/ 10.1080/1350293X.2010.525945

NORDBAKKE, S. (2019). Children's out-of-home leisure activities: Changes during the last decade in Norway. Children's Geographies, 17, 347-360, DOI: https://doi.org/ 10.1080/14733285.2018.1510114

NORMAN, D. (2013). The design of everyday things. New York (Basic Books).

NUTBROWN, C. (2010). Naked by the pool? Blurring the image? Ethical issues in the portrayal of young children in arts-based educational research. Qualitative Inquiry, 17, 3-14.

OVERBEEKE, K. C. J., WENSVEEN S. S. A. G. (2003). From perception to experience, from affordances to irresistibles. In Proceedings of the 2003 international conference on 
designing pleasurable products and interfaces. New York (ACM Press), pp. 92-97. DOI: https://doi.org/10.1145/782896.782919

PERCY-SMITH, B. (2010). Councils, consultations and community: Rethinking the spaces for children and young people's participation. Children's Geographies, 8, 107-122. DOI: https://doi.org/10.1080/14733281003691368

PHELAN, S., KINSELLA, E. A. (2013). Picture this... safety, dignity, and voice - ethical research with children. Qualitative Inquiry, 19, 81-90. DOI: https://doi.org/10.1177/ 1077800412462987

POSPĚCH, P. (2013). Městský veřejný prostor: Interpretativní přístup. Sociologický časopis, 49, 75-100. DOI: https://doi.org/10.13060/00380288.2013.49.1.04

RAUTIO, P. (2013). Children who carry stones in their pockets: On autotelic material practices in everyday life. Children's Geographies, 11, 394-408. DOI: https://doi.org/ $10.1080 / 14733285.2013 .812278$

RAUTIO, P., JOKINEN, P. (2016). Children's relations to the more-than human world beyond developmental views. In Evans, B., Horton, J., Skelton, T., eds. Play and recreation, health and wellbeing. Singapore (Springer), pp. 35-47.

SENDI, R., AALBERS, M. B., TRIGUEIRO, M. (2009). Public space in large housing estates. In Rowlands, R. Musterd, S., van KEMPEN, R., eds. Mass housing in Europe: Multiple faces of development, change and response. Basingstoke (Palgrave Macmillan), pp. 131-156.

SHEN, Y., SUN, F., CHE, Y. (2017). Public green spaces and human wellbeing: Mapping the spatial inequity and mismatching status of public green space in the Central City of Shanghai. Urban Forestry \& Urban Greening, 27, 59-68. DOI: https://doi.org/10.1016/ j.ufug.2017.06.018

SPORREL, K., CALJOUW, S. R., WITHAGEN, R., CORDOVIL, R. (2017). Gap-crossing behaviour in a standardized and a nonstandardized jumping stone configuration. PLoS ONE, 12, 5. DOI: https://doi.org/10.1371/journal.pone.0176165

STEENSON, C. J., RODGER, M. W. (2015). Bringing sounds into use: Thinking of sounds as materials and a sketch of auditory affordances. Open Psychology Journal, 8, 174182. DOI: https://doi.org/10.2174/1874350101508010174

STEVENS, Q. (2007). The ludic city: Exploring the potential of public spaces. New York (Routledge)

STICKDORN, M., LAWRENCE, A., HORMESS, M., SCHNEIDER, J. (2018). This is service design doing: Applying service design thinking in the real world: a practitioner's handbook. Sebastopol (O'Reilly Media).

STORLI, R., HAGEN, T. L. (2010). Affordances in outdoor environments and children's physically active play in pre-school. European Early Childhood Education Research Journal, 18, 445-456. DOI: https://doi.org/10.1080/1350293X.2010.525923

ŠIMÁČEK, P., SZCZYRBA, Z., ANDRÁŠKO, I., KUNC, J. (2015). Humanizace postsocialistických sídlišt' - směřování k lepší kvalitě života. Životné prostredie, 49, 74-81.

ŠVAŘÍČEK, R., ŠEĎOVÁ, K. (2007). Kvalitativni výzkum v pedagogických védách. Praha (Portál).

TERZI, C., TONNELAT, S. (2017). The publicization of public space. Environment and Planning A: Economy and Space, 49, 519-536, DOI: https://doi.org/10.1177/ $0308518 \times 16665359$

THOMPSON, C. W. (2002). Urban open space in the 21st century. Landscape and Urban Planning, 60(2), 59-72. DOI: https://doi.org/10.1016/S0169-2046(02)00059-2

VALENTINE, G. (1997). "Oh yes I can." "Oh no you can't.": Children and parents' understandings of kids' competence to negotiate public space safely. Antipode, 29, 65-89. DOI: https://doi.org/10.1111/1467-8330.00035

Van ANDEL, J. (1990). Places children like, dislike, and fear. Childrens Environments Quarterly, 7(4), 24-31.

WALTERS, S., R., GODBOLD, R. (2014). Someone is watching you: The ethics of covert observation to explore adult behaviour at children's sporting events. Bioethical Inquiry, 11, 531-537. DOI: https://doi.org/10.1007/s11673-014-9543-2 
WILKINSON, P. F., LOCKHART, R. S. LUHTANEN, E. M. (1980). The winter use of playgrounds. In Wilkinson, P. F., ed. Innovation in play environments. London (Routledge), pp. 103-122.

WISHART, L., CABEZAS-BENALCÁZAR, C., MORRISSEY, A., VERSACE, V. L. (2019). Traditional vs naturalised design: A comparison of affordances and physical activity in two preschool playscapes. Landscape Research, 44, 1031-1049. DOI: https:// doi.org/10.1080/01426397.2018.1551524

WOODYER, T. (2012). Ludic geographies: Not merely child's play. Geography Compass, 6, 313-326. DOI: https://doi.org/10.1111/j.1749-8198.2012.00477.x

YAM, R. C. M., WHITFIELD, R. C., RAYMOND, C. W. F. (2000). Forecasting traffic generation in public housing estates. Journal of Transportation Engineering, 126, 358361. DOI: https://doi.org/10.1061/(ASCE)0733-947X(2000)126:4(358)

YATIMAN, N., AZIZ, N., SAID, I. (2012). Affordances of homeschool journey in rural environment for children's performances. Procedia - Social and Behavioral Sciences, 68, 395-405. DOI: https://doi.org/10.1016/j.sbspro.2012.12.236

ZALEWSKI, A., WOJTAK, K. (2020). Possibilities of transformation of public space in multi-family housing estates in Polish conditions - Case of the Bajka estate in Bydgoszcz-Fordon. IOP Conference Series: Materials Science and Engineering, 960. $5^{\text {th }}$ WMCAUS 18 - 19 June 2020, Prague, Czech Republic. DOI: https://doi.org/ $10.1088 / 1757-899 X / 960 / 4 / 042005$

ZOUNEK, F., RUDIŠ, V. (1969). Obytné prostředí pro 20000 obyvatel města Brna. In Roštlapil, V., Zounek, F., ed. Lesná - nová obytná čtvrt’ města Brna: Realizace. Brno (Stavoprojekt), pp. 19-24.

Daniel Kapla

\section{INTERAKCE DĚTí VE VEŘEJNÉM PROSTORU: POZOROVÁNí VNÍMANÝCH AFORDANCÍ DĚTÍ NA SÍDLIŠTTI V BRNĚ, ČESKO}

Tento př́spěvek pracuje s pojmem afordance, který používá jako perspektivu k charakteristice interakce dětí s prostředím, konkrétněji s veřejným prostorem sídlišt'. Afordance mohou být definovány jako vztah mezi vlastnostmi objektu a schopnostmi jedince. Poskytuje jak informace o prostředí nebo předmětu, tak také o osobě, která jej použíá. $Z$ hlediska afordancí hraje významnou roli věk, inteligence a velikost těla, která se postupně vyvíjí a mění stejně jako možnosti interakce s prostředním (Kyttä 2002 a Heft 2010). Cílem tohoto příspěvku je charakterizovat fyzické afordance dětí na sídlišti a také zhodnotit koncept afordance skrze Heftovu taxonomii v urbanizované oblasti.

Sledovaná oblast (sídliště Lesná) se nachází v Brně, Česká republika. Toto sídliště je považováno za jedno $\mathrm{z}$ nejlepších míst $\mathrm{k}$ bydlení v rámci města Brna, mimo jiné i díky všudyprrítomné zeleni. Jedním takovým prvkem na Lesné je Čertova rokle, která umocňuje pocit přírody na sídlišti, prostor dále obohacují sochy rozmístěné po celém sídlišti. Děti byly rozděleny do dvou skupin: větší a menší, protože se u obou skupin předpokládalo odlišné vnímání afordancí. Jako hlavní metoda bylo zvoleno nezúčastněné pozorování. Všechny použité fotografie byly pořízeny se svolením pečovatelů a dítěte a jejich tváře byly později rozmazané. Nedošlo k žádnému shromažd'ování osobních údajů a žádné formální interakci s dětmi. Během výzkumu bylo zkoumáno celé sídliště, následně však došlo $\mathrm{k}$ zaměření pouze na konkrétní místa, která byla typická tím, že tam děti často trávily čas. Hlavní otázka tohoto výzkumu byla: „Jaké fyzické afordance děti zažívají ve veřejném prostoru sídliště?"“

Výsledky klasifikace uvedené $\mathrm{v}$ tabulce 2 poukazují na rozdíly $\mathrm{v}$ konkrétních třídách Heftovy taxonomie $v$ př́ípadě, kdy byly děti rozděleny na větší a menší. Ty větší interagují s prostředím jinak, protože více napodobují chování dospělých. Existovala však místa (napřs. prŕístř̌šky a zákoutí), která se zdála být atraktivnější pro větší děti, které hledají sou- 
kromí a intimitu ve veřejném prostoru. Afordance menších dětí byly rozmanitější a zdálo se, že vznikají častěji ve srovnání s afordancemi větších dětí.

$\mathrm{V}$ rámci tohoto článku bylo $\mathrm{v}$ Heftově taxonomii navrženo několik zásadních úprav, protože jeho klasifikace zcela neodráží specifika veřejných prostranství sídlišt'. Kromě rozdělení podle velikosti dětí musela být trrída vody odstraněna, protože zde nebyl žádný stálý zdroj vody. Na druhou stranu se musela přidat třída sníh, protože má výrazný vliv na aktivity dětí ve veřejném prostoru. Tento článek navrhuje podobné úpravy jako Lerstrupová a van der Bosch (2017) pro Heftovu taxonomii v závislosti na vlastnostech prostředí. I přesto lze najít drobné významové odlišnosti - např́iklad jako faktory ovlivňující afordance dětí byly identifikovány dospělí a dočasnost, zatímco Lerstrupová a van der Bosch zdůrazňují faktory jako novost, hojnost, velikost a další osoby. Celkově lze tvrdit, že výsledky a úpravy navržené v tomto př́spěvku odpovídaly revidované taxonomii Lerstrupové a van der Bosche s nepatrnými rozdíly v závislosti na specifických charakteristikách Lesné.

(c) (1) $\$$ Article first received: October 2020

Article accepted: November 2021 